Vasvari, Louise. "Correction to: Vasvári, Louise O. "The Yellow Star and Everyday Life under Exceptional Circumstances: Diaries of 1944-1945 Budapest." Hungarian Cultural Studies. e-Journal of the American Hungarian Educators Association, Volume 9 (2016) DOI: 10.5195/ahea.2016.260." Hungarian Cultural Studies. e-Journal of the American Hungarian Educators Association, Volume 10 (2017) DOI: 10.5195/ahea.2017.273

\title{
Correction to: Vasvári, Louise O. "The Yellow Star and Everyday Life under Exceptional Circumstances: Diaries of 1944-1945 Budapest." Hungarian Cultural Studies. e-Journal of the American Hungarian Educators Association, Volume 9 (2016) DOI: 10.5195/ahea.2016.260
}

Louise Vasvari, Stony Brook University and New York University louise.vasvari@stonybrook.edu

Abstract: Changing the name Margit Stellar (Mrs. József Krauss) to Anna, a pseudonym, Mrs. Sándor Dévényi, the real name of the writer whose journal is discussed in the article. Also, changing the name Szebenyi to Szebeny.

The original article can be found via the DOI: http://dx.doi.org/10.5195/ahea.2016.260

\section{Errata}

Margit Stellar (Mrs. József Krauss) is a pseudonym used in the original journal written by Anna, Mrs. Sándor Dévényi. At about the time of the publication of this article the journal was published with the real name of the writer, Anna, Mrs. Sándor Dévényi. ${ }^{1}$ The name Margit Stellar (Mrs. József Krauss) was changed to Anna, Mrs. Sándor Dévényi throughout the article.

The spelling of the name Szebényi was changed to the correct spelling, Szebeny ${ }^{2}$, throughout the article.

Full Text Original Article

http://dx.doi.org/10.5195/ahea.2016.260

${ }^{1}$ Huhák, Heléna, András Szécsényi and Erika Szívós (szerk.) 2015. Kismama sárga csillaggal [Expectant Mother with the Yellow Star]. Budapest: Jaffa Kiadó

${ }^{2}$ Szebeny, Klára. 2015. 103 el nem küldött levél Budapest ostromárol [103 Unsent Letters from the Siege of Budapest']. Budapest: Gondolat Kiadó 